\title{
Arthrobacter oryzae sp. nov. and Arthrobacter humicola sp. nov.
}

\author{
Akiko Kageyama, ${ }^{1}$ Kurimi Morisaki, ${ }^{1}$ Satoshi Ōmura ${ }^{1,2}$ \\ and Yoko Takahashi ${ }^{1}$ \\ ${ }^{1}$ Kitasato Institute for Life Sciences, Kitasato University, 5-9-1 Shirokane, Minato-ku, \\ Tokyo 108-8641, Japan \\ ${ }^{2}$ The Kitasato Institute, 5-9-1 Shirokane, Minato-ku, Tokyo 108-8641, Japan
}

Correspondence

Yoko Takahashi

ytakaha@lisci.kitasato-u.ac.jp
The genus Arthrobacter was proposed by Conn \& Dimmick (1947). The type species of the genus, Arthrobacter globiformis, and the closely related species assigned to group III (Stackebrandt \& Schumann, 2000) are characterized by peptidoglycan type $\mathrm{A} 3 \alpha$ with an interpeptide bridge containing one to four molecules of L-alanine (Schleifer \& Kandler, 1972) and MK-9 $\left(\mathrm{H}_{2}\right)$ as the major menaquinone. In this paper, the characterization of two novel species that are closely related to A. globiformis is reported.

Strains $\mathrm{KV}-651^{\mathrm{T}}$ and $\mathrm{KV}-653^{\mathrm{T}}$ were isolated from soil samples collected from a paddy in Saitama prefecture, Japan. Soil ( $2 \mathrm{~g})$ was suspended in $18 \mathrm{ml}$ sterile water and mixed well. Soil particles were allowed to sediment, the liquid phase was diluted $10^{5}$-fold, and $100 \mu \mathrm{l}$ diluted liquid phase was spread onto the surface of GPM agar plates ( $1.0 \%$ glucose, $0.5 \%$ peptone, $0.5 \%$ meat extract, $0.3 \%$ $\mathrm{NaCl}$ and $1.2 \%$ agar, pH 7.0) (Takahashi et al., 2003) supplemented with superoxide dismutase (300 U per plate) and catalase $\left(2100 \mathrm{U}\right.$ per plate) for $\mathrm{KV}-651^{\mathrm{T}}$ or catalase (2100 U per plate) for KV-653 ${ }^{\mathrm{T}}$.

Morphological observations were carried out using a scanning electron microscope (JSM-5600; JEOL) for cultures grown on $1 / 5$ nutrient agar medium at $27{ }^{\circ} \mathrm{C}$ for

The GenBank/EMBL/DDBJ accession numbers for the 16S rRNA gene sequences of Arthrobacter oryzae $\mathrm{KV}-651^{\top}$ and Arthrobacter humicola $\mathrm{KV}-653^{\top}$ are $\mathrm{AB} 279889$ and $\mathrm{AB} 279890$, respectively.

Supplementary tables detailing 16S rRNA gene sequence similarity values and DNA-DNA relatedness values between the two isolated strains and related species and scanning electron micrographs (Fig. S1) and transmission electron micrographs (Fig. S2) of cells of strain KV$653^{\top}$ are available with the online version of this paper.
11-108 h. Motility was determined by microscopic analysis and flagella were observed using a transmission electron microscope (JEM-1200EXII; JEOL) after incubation for $24 \mathrm{~h}$ at $27^{\circ} \mathrm{C}$ on GPM agar medium. Negative staining of cells was performed with $1 \%$ uranyl acetate. Gram-staining was performed by using a Gram-stain reagent kit (Nacalai Tesque). The ability to utilize various carbon sources was tested on basal medium (Pridham \& Gottlieb, 1948) supplemented with $1 \%(\mathrm{w} / \mathrm{v})$ of each carbon source. Tolerance to $\mathrm{NaCl}(0-5 \%$ at intervals of $1 \%)$ was determined on YD agar ( $1.0 \%$ yeast extract, $1.0 \%$ glucose and $1.2 \%$ agar, $\mathrm{pH}$ not adjusted). $\mathrm{pH}$ tolerance was determined on the same medium adjusted to various $\mathrm{pH}$ values ( $\mathrm{pH} 4-11$ at intervals of $1 \mathrm{pH}$ unit) by the addition of $\mathrm{HCl}$ or $\mathrm{NaOH}$. The temperature range for growth was determined on the same medium at $4-45{ }^{\circ} \mathrm{C}$. Biochemical characteristics were determined using the API ZYM (bioMérieux) and API Coryne (bioMérieux) systems in accordance with the manufacturer's instructions.

$\mathrm{N}$-Acyl types of muramic acid were determined by using the method of Uchida \& Aida (1977). Purified cell walls of the isolated strains were prepared as described by Kawamoto et al. (1981) and hydrolysed at $100{ }^{\circ} \mathrm{C}$ with $1 \mathrm{ml} 6 \mathrm{M} \mathrm{HCl}$ for $16 \mathrm{~h}$. Amino acids were derivatized using phenylisothiocyanate and detected using the Pico Tag method (Waters). Cell-wall sugars were prepared according to the method described by Kawamoto et al. (1981) and analysed by cellulose TLC (n-butanol:toluene:pyridine: distilled water at $10: 1: 6: 6$ ). The presence of mycolic acids was examined by using the TLC method of Tomiyasu (1982), and phospholipids were extracted and identified by following the method of Minnikin et al. 


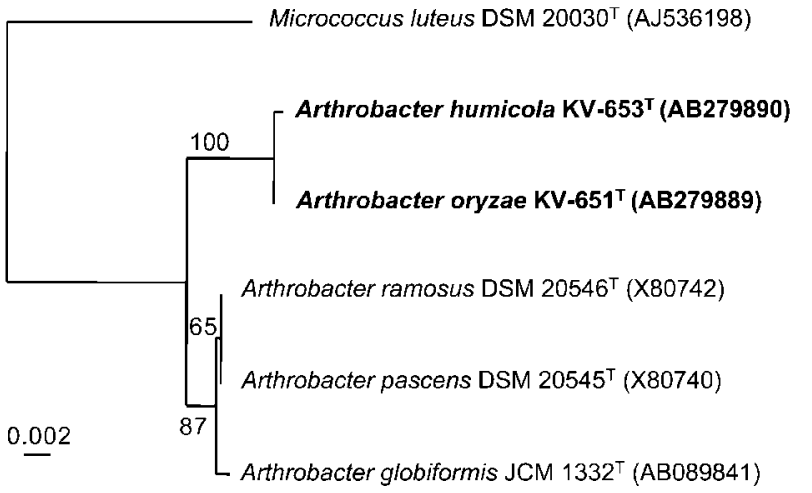

Fig. 1. Phylogenetic tree constructed on the basis of $16 \mathrm{~S}$ rRNA gene sequences using the neighbour-joining method and $K_{\text {nuc }}$ values. Numbers at branching points refer to bootstrap values (1000 resamplings). The tree was unrooted and Micrococcus luteus was used as an outgroup. Bar, $0.002 K_{\text {nuc. }}$.

(1977). Menaquinones were extracted and purified according to Collins et al. (1977) and then analysed by HPLC (802-SC; Jasco) on a chromatograph equipped with a CAPCELL PAK C18 column (Shiseido) (Tamaoka et al., 1983). Methyl esters of cellular fatty acids were analysed by GLC (HP6890; Hewlett Packard). The method in the manual for the Sherlock Microbial Identification System (version 5.0) (MIDI) was used for sample preparation and analysis.

DNA was isolated as described by Saito \& Miura (1963). DNA base composition was estimated by HPLC (Tamaoka \& Komagata, 1984). Levels of DNA-DNA relatedness were determined by using the method of Ezaki et al. (1989).
For $16 \mathrm{~S}$ rRNA gene sequence analysis, DNA was prepared and amplified as reported by $\mathrm{Yu}$ et al. (2002) and Takahashi et al. (2003), respectively, and was sequenced with an automatic sequence analyser (ABI Prism 3130; PE Applied Biosystems) using a dye terminator cycle sequencing kit (PE Applied Biosystems). Sequence data for related species were retrieved from GenBank. Phylogenetic analysis was performed using CLUSTAL W software (Thompson et al., 1994). Nucleotide substitution rates ( $K_{\text {nuc }}$ values) were calculated (Kimura \& Ohta, 1972) and phylogenetic trees were constructed by using the neighbour-joining method (Saitou \& Nei, 1987). Sequence similarity values were determined by visual comparison and manual calculation.

Nearly complete 16S rRNA gene sequences (1465 bp for strain $\mathrm{KV}-651^{\mathrm{T}}$ and $1463 \mathrm{bp}$ for strain $\mathrm{KV}-653^{\mathrm{T}}$ ) were determined. The sequence similarity between the two strains was $99.5 \%$. Phylogenetic analysis demonstrated that the strains belonged to the genus Arthrobacter and were most closely related to A. globiformis, Arthrobacter ramosus and Arthrobacter pascens (Fig. 1) with 98.3-98.9\% sequence similarity (see Supplementary Table S1, available with the online version of this paper).

Both strains KV-651 ${ }^{\mathrm{T}}$ and KV- $653^{\mathrm{T}}$ had a rod-coccus cycle. Their cells were cocci in the stationary growth phase, irregular rods in $11 \mathrm{~h}$-old cultures, predominantly short rods or oval-shaped after $60 \mathrm{~h}$ and had a coccoid shape again after $108 \mathrm{~h}$ (Fig. 2 and Supplementary Fig. S1 in IJSEM Online). Both strains had flagella (Fig. 3 and Supplementary Fig. S2). The cell-wall peptidoglycan of both strains $\mathrm{KV}-651^{\mathrm{T}}$ and $\mathrm{KV}-653^{\mathrm{T}}$ contained lysine, glutamic acid and alanine in the molar ratio of approximately $1: 1:>4$, which suggested that the isolates contained the $\mathrm{A} 3 \alpha$ peptidoglycan type, as observed in $A$.
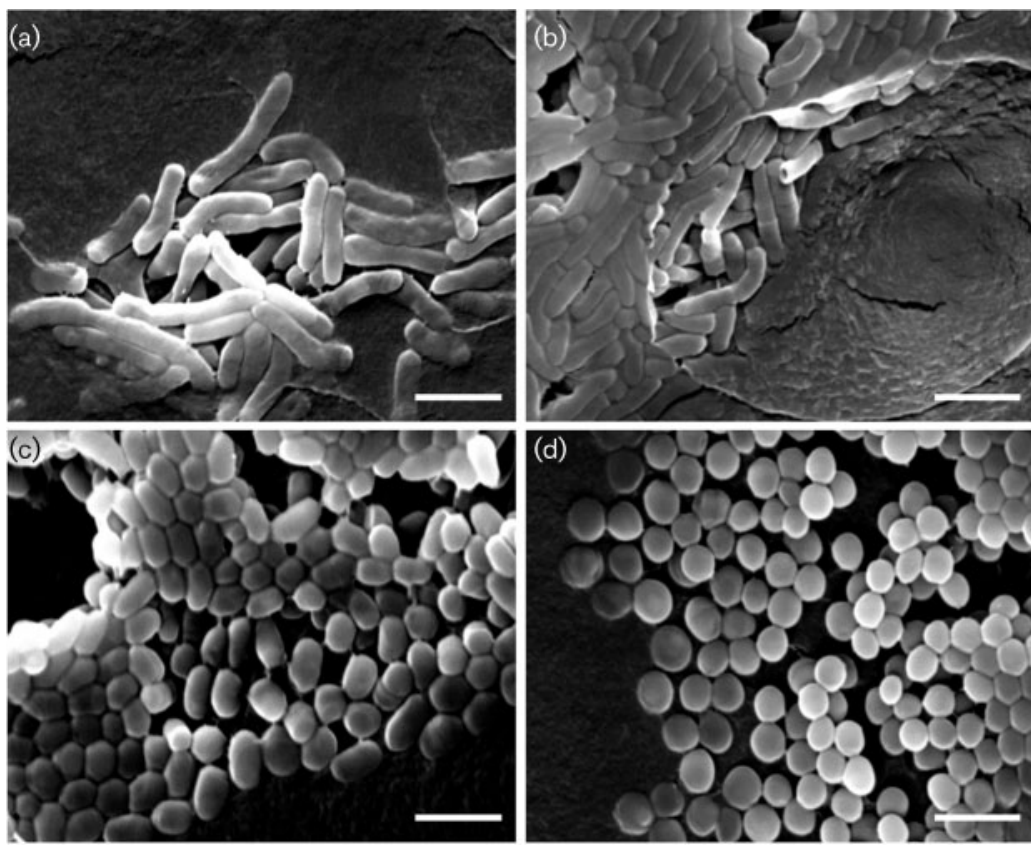

Fig. 2. Scanning electron micrographs of cells of strains $\mathrm{KV}-651^{\top}(\mathrm{a}-\mathrm{d})$ grown on $1 / 5$ nutrient agar medium at $27{ }^{\circ} \mathrm{C}$. Cells are shown after growth for: (a) $11 \mathrm{~h}$; (b) $24 \mathrm{~h}$; (c) $60 \mathrm{~h}$; (d) 108 h. Bars, $2 \mu \mathrm{m}$. 


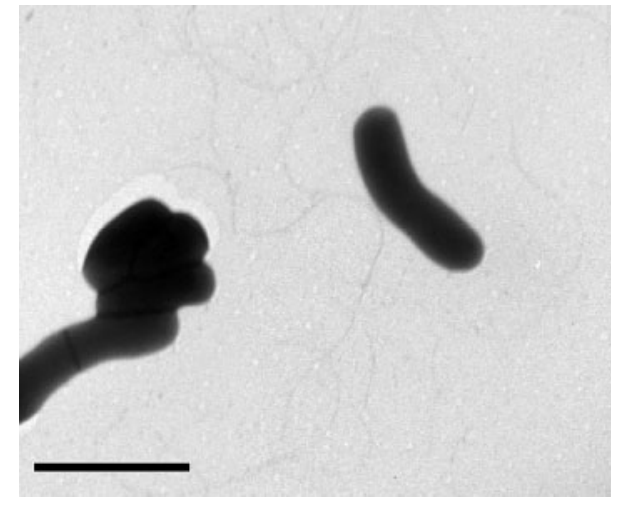

Fig. 3. Transmission electron micrograph of negatively stained cells of strain $\mathrm{KV}-651^{\top}$. Bar, $2 \mu \mathrm{m}$.

globiformis and related species. The predominant menaquinone was MK-9 $\left(\mathrm{H}_{2}\right)$ and the acyl type was acetyl. Mycolic acids were not detected. The cellular fatty acid components of strains $\mathrm{KV}-651^{\mathrm{T}}$ and $\mathrm{KV}-653^{\mathrm{T}}$ were iso- $\mathrm{C}_{15: 0}$ (3.86 and $5.32 \%$ of total, respectively), anteiso- $\mathrm{C}_{15: 0}$ (68.94 and $73.50 \%$, respectively), iso- $\mathrm{C}_{16: 0}$ (3.72 and $6.61 \%$, respectively), $\mathrm{C}_{16: 0}$ (2.97 and $1.15 \%$, respectively) and anteiso$\mathrm{C}_{17: 0}\left(16.61\right.$ and $9.33 \%$, respectively). In addition, iso- $\mathrm{C}_{14: 0}$ $(1.54 \%)$ was detected in strain $\mathrm{KV}-653^{\mathrm{T}}$. Other phenotypic characteristics are given in the species descriptions.

DNA-DNA hybridization values between the two isolates and related Arthrobacter species were less than 50\% (see Supplementary Table S2 in IJSEM Online), well below the $70 \%$ cut-off point for species delineation recommended by Wayne et al. (1987).
A range of phenotypic characters that distinguish strains $\mathrm{KV}-651^{\mathrm{T}}$ and $\mathrm{KV}-653^{\mathrm{T}}$ from each other and from their nearest phylogenetic neighbours is presented in Table 1. For instance, strains $\mathrm{KV}-651^{\mathrm{T}}$ and $\mathrm{KV}-653^{\mathrm{T}}$ differed from the other three Arthrobacter species in their inability to utilize Larabinose and from each other in their cell-wall sugar compositions, $\mathrm{NaCl}$ tolerance and enzymic activities (nitrate reductase, pyrrolidonyl arylamidase and $\alpha$-galactosidase).

Given the results of this study, it is apparent that the isolated strains represent two distinct novel species within the genus Arthrobacter, for which the names Arthrobacter oryzae sp. nov. (strain KV-651 ${ }^{\mathrm{T}}$ ) and Arthrobacter humicola sp. nov. (strain $\mathrm{KV}-653^{\mathrm{T}}$ ) are proposed.

\section{Description of Arthrobacter oryzae sp. nov.}

Arthrobacter oryzae (ory.za'e. L. fem. n. oryzae of rice).

Cells have a rod-coccus cycle. Gram-positive, motile by flagella and aerobic. Colonies are cream coloured on YD agar. Growth occurs on YD agar at initial $\mathrm{pH}$ values between 6 and 11 and at temperatures between 4 and $34{ }^{\circ} \mathrm{C}$. In YD agar medium, up to $2 \% \mathrm{NaCl}$ is tolerated. DGlucose, raffinose, melibiose, D-mannitol, L-inositol and sucrose are assimilated, but L-arabinose and cellulose are not. Leucine arylamidase, acid phosphatase, naphthol-ASBI-phosphohydrolase, $\beta$-glucuronidase and $\alpha$-glucosidase are detected by the API ZYM enzyme assay; the assay is negative for alkaline phosphatase, esterase lipase (C8), trypsin, chymotrypsin, $\alpha$-galactosidase, $\beta$-galactosidase, $\beta$ glucosidase, $N$-acetyl- $\beta$-glucosaminidase, $\alpha$-mannosidase and $\alpha$-fucosidase. Weak reactions are detected for esterase (C4), lipase (C14), valine arylamidase and cystine arylamidase. Nitrate reductase, pyrrolidonyl arylamidase

Table 1. Characteristics of isolates $\mathrm{KV}-651^{\top}$ and $\mathrm{KV}-653^{\top}$ and related Arthrobacter species

Strains: 1 , KV-651 $1^{\mathrm{T}}$; 2, KV-653 $; 3$, Arthrobacter globiformis NBRC $12137^{\mathrm{T}}$; 4, Arthrobacter pascens NBRC $12139^{\mathrm{T}}$; 5, Arthrobacter ramosus NBRC $12958^{\mathrm{T}}$. Data for A. globiformis NBRC $12137^{\mathrm{T}}$, A. pascens NBRC $12139^{\mathrm{T}}$ and A. ramosus NBRC $12958^{\mathrm{T}}$ are from Keddie et al. (1986). +, Positive; w, weakly positive; -, negative; glu, glucose; gal, galactose; man, mannose; rha, rhamnose.

\begin{tabular}{|c|c|c|c|c|c|}
\hline Motility & + & + & - & - & + \\
\hline Cell-wall sugars & gal, glu & gal, rha & gal, glu & gal, glu & gal, man, rha \\
\hline Utilization of L-arabinose & - & - & + & + & + \\
\hline \multicolumn{6}{|l|}{ Enzyme assay (API Coryne): } \\
\hline Urease & - & - & - & - & + \\
\hline \multicolumn{6}{|l|}{ Enzyme assay (API ZYM): } \\
\hline Esterase lipase (C8) & - & $\mathrm{w}$ & - & - & + \\
\hline Acid phosphatase & + & + & - & - & + \\
\hline$\alpha$-Galactosidase & - & + & - & + & - \\
\hline$\beta$-Glucuronidase & + & $\mathrm{W}$ & - & - & + \\
\hline
\end{tabular}


and catalase are detected by the API Coryne enzyme assay, but urease is negative. The diagnostic diamino acid of the peptidoglycan is lysine. The acyl type of the peptidoglycan is acetyl. The major menaquinone is $\mathrm{MK}-9\left(\mathrm{H}_{2}\right)$. The major cellular fatty acids are anteiso- $\mathrm{C}_{15: 0}$, anteiso- $\mathrm{C}_{17: 0}$ and iso$\mathrm{C}_{15: 0}$. Cell-wall sugars contain galactose and glucose. The DNA $\mathrm{G}+\mathrm{C}$ content of the type strain is $67 \mathrm{~mol} \%$.

The type strain, KV-651 ${ }^{\mathrm{T}} \quad\left(=\mathrm{NRRL} \quad \mathrm{B}-24478^{\mathrm{T}}=\mathrm{NBRC}\right.$ $102055^{\mathrm{T}}$ ), was isolated from paddy soil, Japan.

\section{Description of Arthrobacter humicola sp. nov.}

Arthrobacter humicola (hu.mi.co'la. L. masc. n. humus soil; L. suff. -cola dweller; N.L. masc. or fem. n. humicola soil dweller).

Cells have a rod-coccus cycle. Gram-positive, motile by flagella and aerobic. Colonies are cream coloured on YD agar. Growth occurs on YD agar at initial $\mathrm{pH}$ values between 6 and 10 and at temperatures between 4 and $34{ }^{\circ} \mathrm{C}$. In YD agar medium, up to $3 \% \mathrm{NaCl}$ is tolerated. D-Glucose, D-xylose, raffinose, melibiose, D-mannitol, L-rhamnose, L-inositol and sucrose are assimilated, but $\mathrm{L}$-arabinose and cellulose are not. Esterase (C4), leucine arylamidase, cystine arylamidase, acid phosphatase, naphthol-AS-BI-phosphohydrolase, $\alpha$-galactosidase and $\alpha$-glucosidase are detected by the API ZYM enzyme assay; the assay is negative for alkaline phosphatase, trypsin, chymotrypsin, $\beta$-glucuronidase, $N$-acetyl- $\beta$-glucosaminidase and $\alpha$-fucosidase. Weak reactions are detected for esterase lipase (C8), lipase (C14), valine arylamidase, $\beta$ galactosidase, $\beta$-glucosidase and $\alpha$-mannosidase. Catalase is detected by the API Coryne enzyme assay, but nitrate reductase, pyrrolidonyl arylamidase and urease are negative. The diagnostic diamino acid of the peptidoglycan is lysine. The acyl type of the peptidoglycan is acetyl. The major menaquinone is MK- $9\left(\mathrm{H}_{2}\right)$. The major cellular fatty acids are anteiso- $\mathrm{C}_{15: 0}$, anteiso- $\mathrm{C}_{17: 0}$ and iso- $\mathrm{C}_{16: 0}$. Cell-wall sugars contain galactose and rhamnose. The DNA G $+\mathrm{C}$ content of the type strain is $67 \mathrm{~mol} \%$.

The type strain, KV-653 ${ }^{\mathrm{T}} \quad\left(=\mathrm{NRRL} \quad \mathrm{B}-24479^{\mathrm{T}}=\mathrm{NBRC}\right.$ $102056^{\mathrm{T}}$ ), was isolated from paddy soil, Japan.

\section{Acknowledgements}

We thank Atsuko Matsumoto, Megumi Fukumoto and Emi Ariki of the Kitasato Institute for Life Sciences, Kitasato University for the TEM analysis. This study was supported in part by a Grant of the 21st Century COE Program from the Ministry of Education, Culture, Sports, Science and Technology (MEXT) and The JSPS Grant-in-Aid for Science Research Foundation.

\section{References}

Collins, M. D., Pirouz, T., Goodfellow, M. \& Minnikin, D. E. (1977). Distribution of menaquinones in actinomycetes and corynebacteria. J Gen Microbiol 100, 221-230.

Conn, H. J. \& Dimmick, I. (1947). Soil bacteria similar in morphology to Mycobacterium and Corynebacterium. J Bacteriol 54, 291-303.
Ezaki, T., Hashimoto, Y. \& Yabuuchi, E. (1989). Fluorometric deoxyribonucleic acid-deoxyribonucleic acid hybridization in microdilution wells as an alternative to membrane filter hybridization in which radioisotopes are used to determine genetic relatedness among bacterial strains. Int J Syst Bacteriol 39, 224-229.

Kawamoto, I., Oka, T. \& Nara, T. (1981). Cell wall composition of Micromonospora olivoasterospora, Micromonospora sagamiensis, and related organisms. J Bacteriol 146, 527-534.

Keddie, R. M., Collins, M. D. \& Jones, D. (1986). Genus Arthrobacter Conn and Dimmick 1947, 300 ${ }^{\mathrm{AL}}$. In Bergey's Manual of Systematic Bacteriology, vol. 2, pp. 1288-1301. Edited by P. H. A. Sneath, N. S. Mair, M. E. Sharpe \& J. G. Holt. Baltimore: Williams \& Wilkins.

Kimura, M. \& Ohta, T. (1972). On the stochastic model for estimation of mutation distance between homologous proteins. J Mol Evol 2, 87-90.

Minnikin, D. E., Patel, P. V., Alshamaony, L. \& Goodfellow, M. (1977). Polar lipid composition in the classification of Nocardia and related bacteria. Int Syst Bacteriol 27, 104-117.

Pridham, T. G. \& Gottlieb, D. (1948). The utilization of carbon compounds by some Actinomycetales as an aid for species determination. J Bacteriol 56, 107-114.

Saito, H. \& Miura, K. (1963). Preparation of transforming deoxyribonucleic acid by phenol treatment. Biochim Biophys Acta 72, 619-629.

Saitou, N. \& Nei, M. (1987). The neighbor-joining method: a new method for reconstructing phylogenetic trees. Mol Biol Evol 4, 406-425.

Schleifer, K. H. \& Kandler, O. (1972). Peptidoglycan types of bacterial cell walls and their taxonomic implications. Bacteriol Rev 36, 407-477.

Stackebrandt, E. \& Schumann, P. (2000). Introduction to the taxonomy of Actinobacteria. In The Prokaryotes: an Evolving Electronic Resource for the Microbiological Community, 3rd edn, release 3.3, September 9, 2000. Edited by M. Dworkin and others. New York: Springer.

Takahashi, Y., Katoh, S., Shikura, N., Tomoda, H. \& Ōmura, S. (2003). Superoxide dismutase produced by soil bacteria increases bacterial colony growth from soil samples. J Gen Appl Microbiol 49, 263-266.

Tamaoka, J. \& Komagata, K. (1984). Determination of DNA base composition by reversed-phase high-performance liquid chromatography. FEMS Microbiol Lett 25, 125-128.

Tamaoka, J., Katayama-Fujimura, Y. \& Kuraishi, H. (1983). Analysis of bacterial menaquinone mixtures by high performance liquid chromatography. J Appl Bacteriol 54, 31-36.

Thompson, J. D., Higgins, D. G. \& Gibson, T. J. (1994). ClustaL W: improving the sensitivity of progressive multiple sequence alignment through sequence weighting, position specific gap penalties and weight matrix choice. Nucleic Acids Res 22, 4673-4680.

Tomiyasu, I. (1982). Mycolic acid composition and thermally adaptative changes in Nocardia asteroides. J Bacteriol 151, 828-837.

Uchida, K. \& Aida, K. (1977). Acyl type of bacterial cell wall: its simple identification by colorimetric method. J Gen Appl Microbiol 23, 249-260.

Wayne, L. G., Brenner, D. J., Colwell, R. R., Grimont, P. A. D., Kandler, O., Krichevsky, M. I., Moore, L. H., Moore, W. E. C., Murray, R. G. E. \& other authors (1987). International Committee on Systematic Bacteriology. Report of the ad hoc committee on reconciliation of approaches to bacterial systematics. Int J Syst Bacteriol 37, 463-464.

Yu, L., Takahashi, Y., Matsumoto, A., Seino, A., Iwai, Y. \& Ōmura, S. (2002). Application of PCR for selection of Gram-positive bacteria with high DNA G + C content among new isolates. Actinomycetologica $16,1-5$. 